\title{
The Tragic Cost of Human Life from COVID 19 by Government Leaders Who Deny Evidenced Based Science
}

\author{
Robert W Buckingham* and Renata Ferretti \\ University of Michigan - Flint, Michigan, USA \\ *Corresponding Author: Robert W Buckingham, University of Michigan - Flint, \\ Michigan, USA.
}

Received: July 06, 2021

Published: August 05, 2021

(C) All rights are reserved by Robert $\mathbf{W}$

Buckingham and Renata Ferretti.

\begin{abstract}
The denial of science has proven deadly for many countries especially Brazil and the United States. The Bolsanaro and Trump presidencies have cost many lives of Brazilians and Americans. The failure to listen to evidence-based science with respect to COVID 19 has increased number of cases and deaths to the people of Brazil and the United States. There appears to be a political war on science by some administrations. Presidents and Prime Ministers must listen to evidence base science and recommend appropriate public health policy to safeguard the health of its populace.
\end{abstract}

Keywords: Covid 19; Leadership; Public Health Policy; Evidence-based Science; Brazil; United States of America

\section{Introduction}

When Presidents and leaders of countries are denying facts, science, and scientific evidence, then the public health of the nation is in danger. That is exactly what happened to Brazil. On June 19, 2021, Brazil has just surpassed the record of 500,00 deaths from Covid 19.

Scientists must be involved in public policy decision making in a health crisis like we now face with COVID 19. Leaders of countries must rely on scientists to aid in the decision making of public policy. These important decisions will affect the health of its populace as well as the economy.

The denial of science by governmental leaders

The denial of science by governmental leaders is a tragic event which leads to unnecessary disease and death of its citizens. One cannot separate public health from politics since we are addressing the health of the people. While politicians must use the scientific process to make careful policies and create programs that benefit public health, scientists must avoid being drawn into the political fray and influencing elections [1]. However, perhaps we should carefully select our leaders who believe in evidence-based science and will make public policy from that standpoint.

The primary responsibility of any leader is to protect its citizens. Clearly the health of the nation is part of the leader's duties. The health of the nation is of primary intent of the leader. The goal of any President or Prime Minister is to bring the nation to a better place than when he or she took the position. Decisive leadership is characterized by rapid response based on a clear understanding of the threat posed by any pandemic like what we are facing with the COVID-19. Any delayed action could lead to worse outcomes [2]. As a key factor in determining success, decisive leadership from political and public health leaders is emerging around the world. Unfortunately, there appears to be some leaders who are living in a post truth environment such as former President Trump of the United States and President Bolsonaro of Brazil. They have appeared to be Anti Science and revolved around a popularism platform.

Science must play a primary role in the handling of any pandemic that faces the world populace. Presidents and Prime Ministers 
must embrace science and technology to protect and preserve the health of their people. Only then will the respective nation will find itself in a better place. It appears that countries like Germany and New Zealand have shown interest in science-based leadership directives. The New Zealand President has worked closely with the country's chief public health officer. She avoided criticizing, undermining, or speculating about the virus, which was critical in managing the response. If Presidents ignore science from a strategy perspective, they are putting themselves and their people in a very dangerous position. The death toll in New Zealand is dramatically lower than the thousands of deaths seen in other countries [3]. However, countries like Brazil and the US have been slow or hesitant to respond to the early pandemic issues facing their people. It almost appears that Brazil's leadership has been anti-science. Certainly, a sad commentary for the many Brazilians who are facing the ravages of Covid and its many deaths.

Comparative pandemic management between United States and Brazil

Former US President Donald Trump was reluctant to institute a national lockdown and repeatedly flouted the advice of the country's top infectious disease experts. He pitted public health against economics, saying "the cure cannot be worse than the problem", and promoted hydroxychloroquine and another unproven treatment for COVID-19. Trump has waited months to embrace the CDC scientists' message for the public to wear masks to prevent the virus from spreading, and he has often appeared at his own political rallies without one. The president later told the public not to be "afraid of COVID" after contracting it in October, even as thousands of Americans died from the virus each day [3].

In Brazil, President Jair Bolsonaro denied the seriousness of the virus even after contracting it and promoted unproven treatments for COVID-19, such as hydroxychloroquine. He also expresses skepticism about the effectiveness of the COVID-19 vaccine and avoids wearing masks in public, leading to a politicization of a simple public health recommendation. In addition, the Brazilian Health Ministry has decided not to buy millions of vaccine doses in 2020, insisting that Brazil would produce vaccines, but the pace did not keep up with demand [3].

Undoubtedly, the behavior of Trump and Bolsonaro having dealt with the Pandemic has been very harmful to both countries. In the graphic below (Figure 1), it is possible to see when the curve of cases and deaths starts to decrease in the United States as Biden assumes the presidency of the United States and changes the way the federal government responds to the COVID-19 Pandemic. On another hand, the mistaken way of managing the pandemic by the Bolsonaro Government resulted in an increase in the number of cases and deaths.

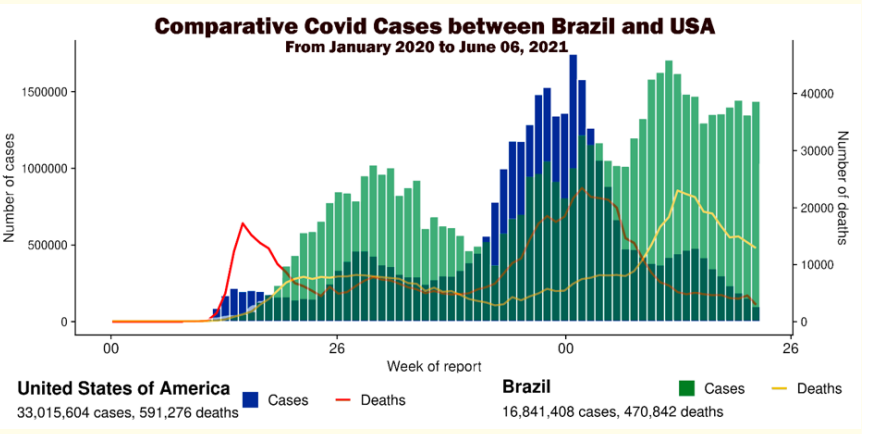

Figure 1: Comparative Covid Cases between Brazil and USA, from January 2020 to June 06, 2021. The chart was adapted from the World Health Organization [4].

In direct contrast to his predecessor, President Joe Biden is treating the pandemic as a national-scale crisis that requires a comprehensive national strategy. Over the first 100 days in office, John Biden's administration has distributed 290 million shots, administered more than 230 million, and about 96 million Americans are fully vaccinated, which represents $29 \%$ of the population [5]. Under Biden's administration, daily new cases fell 73 percent from an average of more than 199,000 in the week before he took office to about 54,400 cases by the end of April [6].

A leader's competence over a public health crisis can be a matter of life or death for its citizens. If the leader does not take the public health crisis seriously it will be difficult to convince citizens to do so. (Vinopal, home) In Brazil, President Bolsonaro is an avid COVID-19 denier and strong critic of vaccination, especially vaccines from China. According to Gramacho and Turgeon (2608), Brazilian citizens who positively evaluate President Bolsonaro are significantly less inclined to vaccinate than those who have negative opinions about him. Brazilians are significantly less likely to vaccinate if they know that the vaccine was developed in China and Russia, compared to those developed in the United States and England. Rejection of the Chinese vaccine is strongest among those who rate President Bolsonaro positively. In this scenario, Brazil is moving slowly in its vaccination campaign, as can be seen in the figure below (Gramacho and Turgeon, 2608). 


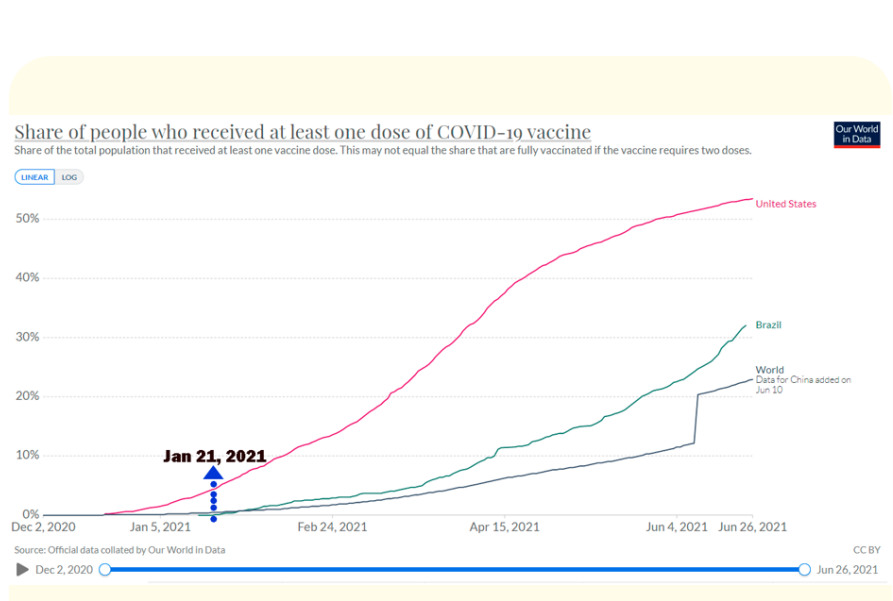

Figure 2: Share of people who received at least on dose of COVID-19 vaccine - comparison between United States and Brazil. Our World in Data, 2021. Adapted.

Figure 2 shows that at the end of June 2021, the United States under the Biden Administration vaccinated $53 \%$ of the population, which represents more than 322 million people with at least one shot of the vaccine, and $42 \%$ of the population is fully vaccinated. While only $32 \%$ of the Brazilian population had received at least the first vaccine dose, which means around 92 million people [7]. However, it is important to emphasize at January 21, 2021, when Biden assume the President of the United States, only 4,5\% of the population had received at least one shot, as it is possible to identify in figure 2 [8].

\section{Conclusion}

Science based leadership is a must for every world leader to contemplate, consider and implement to protect and preserve the health of its people. If every leader can protect the health and well being of its people then the world will be in a better place.

It is the opinion of the authors that evidence-based science can improve and protect the lives of the world populace. Henceforth, it is important that each country elect leaders who embrace science and will recommend public health policy to insure the protection of its people. Our leaders must confront disinformation. Our leaders must not reject scientific findings for the purpose to appease and satisfy small interest groups. Our leaders must serve to protect the health and well being of the people they serve by initiating evidence-based science into it policy decisions.

\section{Bibliography}

1. William L Roper. "Science, politics, and public health". Editorial Science by the American Association for the Advancement of Science, Washington, DC 370.6515 (2020).

2. Obaid Al Saidi Mohammed., et al. "Decisive leadership is a necessity in the COVID-19 response". The Lancet 396 (2020).

3. Vinopal Courtney. "What we've learned about leadership from the COVID-19 pandemic".

4. World Health Organization. "WHO COVID-19 Explorer Geneva - COVID Intel Database”. Brazil and United States chart (2021).

5. Reuters. "Biden's first 100 days: COVID-19, jobs, foreign policy, immigration, guns and dogs”. April 27, (2021).

6. Breslow Jason. “Biden's 1st 100 Days: A Look By The Numbers". NPR media organization. April 27, (2021).

7. Our World in Data. "Statistics and Reserarch - Coronavirus (COVID-19) Vaccinations".

8. PBS News Hour, April 6, (2021).

\section{Volume 4 Issue 9 September 2021 (C) All rights are reserved by Robert W Buckingham and Renata Ferretti.}

